\author{
Barbara Bogołębska \\ Uniwersytet Łódzki \\ Katedra Dziennikarstwa i Komunikacji Społecznej
}

\title{
LĘK JAKO DOMINUJĄCE UCZUCIE W NARRACJACH LITERACKICH I NIELITERACKICH GRAŻYNY I WOJCIECHA JAGIELSKICH
}

\section{Streszczenie}

Artykuł omawia pod kątem uczucia lęku utwory Grażyny i Wojciecha Jagielskich (wspomnienia, książki reporterskie, powieści). Są to zarówno lęki wojenne, jak i rodzinne. Emocjom towarzyszą opisy psychiki bohaterów i skutków wojen.

Słowa kluczowe: lęk, narracja literacka, narracja nieliteracka, książka reporterska, korespondent wojenny

\footnotetext{
Summary

Fear as a dominant feeling in literary and non-literary narration of Grażyna and Wojciech Jagielski

The article examines the works of Grażyna and Wojciech Jagielski (remembrances, reporter's books, novels) from an angle of fear feelings like war fear and family fear. The emotions are accompanied by descriptions of heroes' psyche and effects of war.
}

Keywords: fear, literary narration, non-literary narration, reporter`s books, war correspondent

Literackie korzenie dziennikarstwa, jego powinowactwa z literaturą są oczywiste. Dziennikarstwo nazywa się nawet literaturą XXI wieku ${ }^{1}$. Jest wiele przykładów przekraczania i poszerzania granic publicystyki i literatury (na przykład w reportażu literackim). Skoro żyjemy w czasach hybrydycznych, „ruchomych granic literatury", często bohaterowie fikcyjni posiadają cechy bohaterów realnych.

1 Por. na ten temat: Dziennikarstwo a literatura $w$ XX i XXI wieku, red. K. Wolny-Zmorzyński, W. Furman, J. Snopek, Warszawa 2011; Mistrzowie literatury czy dziennikarstwa?, red. K. Wolny-Zmorzyński, W. Furman, J. Snopek, Warszawa 2011. 
Grażyna Jagielska to dziennikarka, tłumaczka i autorka utworów fikcjonalnych i niefikcjonalnych, żona znanego reportażysty Wojciecha Jagielskiego, korespondenta zagranicznego „Gazety Wyborczej”, przebywającego podczas konfliktów zbrojnych w Azji Środkowej, na Kaukazie oraz w Afryce, autora książek reporterskich, obecnie pracownika PAP.

O afekcie lęku - który można odnaleźć w ich tekstach - pisał następująco Arystoteles: „jest to przykrość i niepokój wywołane wyobrażeniami o grożącym nieszczęściu, które niesie zgubę lub cierpienie”2. Odczucie lęku o coś / o kogoś, bojaźń, trwoga, obawa i przerażenie przed śmiercią, niebezpieczeństwem i nieznanym.

Wojciech Jagielski, który nie uważa się za korespondenta wojennego, a korespondenta „z wojen”, bywał na pierwszej linii walk i nieraz miał świadomość ryzyka i zagrożenia, wypowiadał się następująco na temat strachu:

Zawsze odczuwałem i odczuwam strach podczas dziennikarskich wyjazdów na wojny. Uczucie strachu uważam za normalne i pomocne. Wiele razy uratowało mnie przed zrobieniem jeszcze tego jednego kroku, który okazałby się ostatnim. Uważam wręcz, że ktoś, kto strachu nie odczuwa, nie powinien nigdy wybierać się w miejsca niebezpieczne. Strach nie jest uczuciem przyjemnym, jednak nie wolno mi się nim kierować przy podejmowaniu decyzji o wyjeździe. To był mój wybór, który już raz został dokonany. Dla mnie jest to oczywiste. Chciałem być dziennikarzem, chciałem pisać i podróżować po Afryce i Azji. Redakcja zaakceptowała mój wybór. Nie mogę więc kręcić nosem, marudzić, zastrzegać się, dokąd mogę jechać, a gdzie moja noga nie postanie. Stany lękowe czy potrzeba przeżywania przygód, narażania się na niebezpieczeństwo to prywatna sprawa dziennikarzy. Jeśli jednak poważnie traktuje się swój zawód, pasję, swoich czytelników i samego siebie, trzeba być konsekwentnym. Skoro postanowilem pisać o Afryce, to musze pisać też o tamtejszych wojnach i oglądać je możliwie z jak najmniejszej odległości. Trzeba mieć świadomość, że wyjeżdżając do krajów, w których toczy się wojna, po prostu naraża się życie ${ }^{3}$.

Jagielski miał także świadomość, że cenę za relację korespondentów z konfliktów zbrojnych płaci rodzina dziennikarza, który wystawia swoich bliskich na niebezpieczeństwo. Wiedział również, że dla partyzantów, na przykład w Afganistanie, jest nieprzyjacielem z Zachodu. Pisał też: „Zawsze akceptowałem to, że wyruszając w podróż do ludzi, którzy żyją w zagrożeniu, sam też będę musiał wystawić się na niebezpieczeństwo albo przynajmniej pogodzić się z tym, że nikt nie zapewni mi bezpieczeństwa"4.

2 Arystoteles, Retoryka. Poetyka, przeł. H. Podbielski, Warszawa 1988, s. 182.

3 W. Jagielski, Nie wybratem sobie wojen, [w: ] Biblia dziennikarstwa, red. A. Skworz, A. Niziołek, Kraków 2010, s. 241-242.

4 Ibidem, s. 243. 
Dziennikarstwo wojenne („wydarzeniowe”) jest swoistym uzależnieniem, a ceną, jaką się za nie płaci, bywają depresja, choroba nerwowa, obłęd, a nawet samobójstwo.

We wspomnieniach Mitość $z$ kamienia. Życie z korespondentem wojennym ${ }^{5}$ Jagielska opisuje swoje przeżycia jako pacjentki kliniki psychiatrycznej leczącej tzw. stres bojowy (,jest to stres mojego męża”, jego lęki, niepokój) jako skutek ciągłego zagrożenia życia własnego i życia męża. „Dom zdrowia psychicznego”, leczący choroby nerwowe pacjentów, usytuowany był z dala od telefonów przekazujących złe wiadomości. Autorka bała się jednak końca pobytu w zakładzie, nie czuła się wyleczona, obawiała się powrotu koszmarnych wizji. Tymczasem zajęcia terapeutyczne, w których uczestniczyła, przebywając w klinice, pozwalały jej być szczęśliwą.

Jagielska przed wyprawami męża starała się zachować pogodę ducha, zachowywać się naturalnie, by mu w ten sposób pomóc - była to jednak tylko gra pozorów. Podczas nieobecności męża żyła „w zawieszeniu między życiem a śmiercią": w samotności, w nieustannym zagrożeniu, cierpiała, ze strachu i bezradności nie czuła się bezpiecznie, tym bardziej że wiedziała, iż giną także dziennikarze, mimo wyposażenia w kamizelki kuloodporne. Jak pisała: „Strach przed tym, co się ze mną stanie, kiedy on wyjdzie z domu, był gorszy niż jego nieobecność”. Zazdrościła tym znajomym, którzy wojny nie znali, a więc się jej nie bali. Mąż opowiadał jej o tym, że zdarzało się, iż dla własnego bezpieczeństwa żył przebrany za Czeczena, że korespondentów zagranicznych sprzedawano porywaczom za dolary. Drastyczne obrazy z opowieści reportera o wybuchu, który rozerwał gruzińskiego przewodnika Meraba Kakubawę, czy o ofierze gwałtu Tai niczym koszmary wciąż wracały w wyobraźni Jagielskiej. Żyła ona w poczuciu ciągłego zagrożenia, więc nie potrafiła prowadzić domu, zajmować się dziećmi, pracować. Jak pisała: „Tkwiłam już przy telefonie albo przed ekranem telewizora. Nie chodziłam do pracy, do sklepu po chleb, na wywiadówki w szkole"7. Bała się nadejścia złych wiadomości o mężu. Dźwięk telefonu budził w niej grozę, „rozrywał powietrze na strzępy, robił sobie we mnie korytarze”. Nie panowała nad swoim życiem. Przebywała w przedpokoju, „we wnęce na szafę ścienną”. W jej wspomnieniach czytamy:

5 G. Jagielska, Miłość z kamienia. Życie z korespondentem wojennym, Kraków 2013.

6 Ibidem, s. 170.

7 Ibidem, s. 55.

8 Ibidem, s. 124. 
[...] próbowałam odwlec moment, kiedy Massud wejdzie na stałe w naszą codzienność, wkręci się w nią jak przedtem Omar ochroniarz i gwałcona Taja, zagarnie kolejny kawałek naszego wspólnego życia. Nie wiedziałam, dlaczego to jest takie groźne, ale nie chciałam tych wszystkich ludzi w swoim domu. Zagnieżdżali się, byli w notatkach na biurku, przy stole, w naszych rozmowach, od słowa do słowa wchodzili w meble. Ciągle znajdowałam po nich jakieś ślady ${ }^{9}$.

Życie małżonków podzielone było na okresy oczekiwania i powrotów. Oprócz tego, że dziennikarz „przywoził” ze sobą różnych ludzi, to jeszcze „sporo samego siebie zostawiał po tej drugiej stronie” - „dostaje opowieści, ale sporo oddaje w zastaw”" Tak więc wspólne życie, codzienność wypełniały zapamiętane wydarzenia i ludzie. Te dwa „równoległe światy” przenikały się. Jagielscy żyli „zamknięci każde w swojej udręce”. Konsekwencją przeżyć, nieustannie odczuwanego lęku był kryzys małżeński, o którym Jagielska szczerze pisze: „Byliśmy oboje na skraju wytrzymałości. Nie wiem, czego nie mógł wytrzymać Wojtek - nie potrafiliśmy się już porozumieć [... ]" ${ }^{11}$. Autorka żyła w zawieszeniu między życiem a śmiercią. Strach zmienił także jej postrzeganie samej siebie. Mąż oczekiwał od niej, że zapewni mu poczucie bezpieczeństwa, lecz tej roli nie sprostała. Trzykrotnie towarzyszyła mu na wojnie, dzieląc jego przeżycia i strach: „Jadąc razem na wojnę, mieliśmy zburzyć dzielącą nas barierę, odnaleźć to, co nas kiedyś łączyło" ${ }^{2}$. Strach przeżywany w Kaszmirze, Sri Lance i Afganistanie umocnił ją w przekonaniu, że już nigdy nie pojedzie w rejon wojny. Uchroniła męża przed depresją, obłędem, samobójstwem, sama płacąc cenę własną chorobą. Jakże dramatyczne słowa wypowiedziała w końcowej części wspomnień:

Jesteśmy w symbiozie z Wojtkiem [... . Boimy się, że on zginie, ponieważ to będzie oznaczało naszą śmierć, tak czujemy. Zrozumiałe, skoro jesteśmy z Wojtkiem jednym organizmem. Poprzez jego śmierć boimy się własnej. Nie chcemy umierać. Boimy się tak bardzo, że już nie umiemy żyć ${ }^{13}$.

Reporter zrezygnował z wyjazdów na wojny, by nie być dłużej źródłem strachu, jednak Jagielska bała się, że jest to tylko „zawieszenie egzekucji”.

Strach oddawała autorka także metaforycznie, na przykład pisząc o sobie, iż „boi się tak bardzo, że woli się nie ruszać, jak zagrożony zaskroniec nieruchomieje i udaje coś innego" ${ }^{14}$. A oto inny przykład reakcji na obserwowane działania

\footnotetext{
9 Ibidem, s. 73-74.

10 Ibidem, s. 76.

11 Ibidem, s. 66.

12 Ibidem, s. 89.

13 Ibidem, s. 196.

14 Ibidem, s. 117.
} 
wojenne: „Z wąwozu, jak ze smoczej paszczy, wydobywały się dymy, pomruki i świsty. Co jakiś czas wylatywała rakieta i albo szła górą, albo wybuchała, trafiając w przeciwległą ścianę. Stałam nad brzegiem rzeki, wlepiając oczy w tę gardziel, oniemiała ze zgrozy $[\ldots]^{\prime 15}$.

Anioły jedza trzy razy dziennie ${ }^{16}$ to książka Jagielskiej dedykowana weteranom wojen w Iraku i w Afganistanie, którzy dzielili z autorką pobyt w Klinice Psychiatrii i Stresu Bojowego w Warszawie (stąd podtytuł: 147 dni w psychiatryku). Powrót z wojny nie pozwalał im żyć jak dawniej. Poznajemy ich sylwetki, przeżycia i zachowania: szeregowego Mazura, Adama - strzelca pokładowego, Marka - bohatera z Afganistanu („Afganu”), Ratownika, Sapera i innych. Po przeżyciach wojennych pozostał płacz, niechciane wspomnienia, „widziadła” z przeszłości, załamania, „ataki rozpaczy i buntu”, krzyki („krzyczał [...] wieczorami, szukając we wraku rosomaka nóg przyjaciela" $\left.{ }^{17}\right)$. Jedni weterani próbowali ucieczki, inni - unikali rozmów o traumatycznych zdarzeniach, szukali odosobnienia albo też odreagowywali agresją. Wciąż mieli w pamięci to, że na przykład „nie udało się wyciągnąć kumpla ze zmiażdżonego pojazdu pancernego" ${ }^{18}$. Okaleczeniom ciała (urwane nogi Marka - amputacja) towarzyszyły „okaleczenia duszy”. Jak czytamy: „Flashbacki to nawracające obrazy traumatycznego zdarzenia, które wywołało zespół stresu pourazowego" ${ }^{19}$. Obraz śmierci kolegów ginących w rosomakach i drastyczne sceny zaobserwowane na polu walki sprawiały, że ze strachu przed zasadzkami talibów lub zabijaniem niewinnych cywilów, którymi osłaniali się talibowie (na przykład dziecko pasterz wzięte za terrorystę i zabite), żołnierze pili, popełniali samobójstwa. Antidotum na „chorobę duszy” i pomocą w nauce życia były w klinice wygłaszane przez pacjentów życiorysy lub uczestniczenie w psychodramach: „Czasem chcą rozmawiać z Afganistanem [...]. Albo z Irakiem, czasem ze śmiercią albo z jakąś zmorą, przez którą nie mogą normalnie żyć” ${ }^{20}$. Na podstawie rozmów pacjentów, ich wspomnień poznajemy warunki życia $\mathrm{w}$ bazie $\mathrm{w}$ Afganistanie czy też problemy w kontaktach $\mathrm{z}$ rodzinami pozostawionymi w Polsce. $Z$ perspektywy czasu żołnierze żałowali udziału w misji pokojowo-stabilizacyjnej.

W latach 1994-1996 Grażyna Jagielska odbyła podróże dziennikarskie do Kaszmiru i na Sri Lankę. Reminiscencje z powstania kaszmirskiego i wojny afgańskiej z 1996 roku odnajdujemy w utworze z pogranicza fikcji

\footnotetext{
15 Ibidem, s. 142.

16 G. Jagielska, Anioły jedza trzy razy dziennie, Kraków 2014.

Ibidem, s. 43.

18 Ibidem, s. 18.

19 Ibidem, s. 44.

20 Ibidem, s. 111.
} 
i non-fiction zatytułowanym Korespondent ${ }^{21}$, którego bohaterami są Caroline i Adam Matyasowie - korespondenci wojenni (nazywani „ścigantami”) przebywający w Delhi.

Dziennikarze przeżywali kryzysy i załamania nerwowe. Z książki dowiadujemy się o niezbędnych w zawodzie korespondentów zagranicznych miejscowych opiekunach (tłumaczach, przewodnikach), o ciągłym oczekiwaniu, by zdobyć newsy na pierwsze strony gazet i czołówki telewizyjnych serwisów, o tym, że „trzeba się było spieszyć, być zawsze o krok przed innymi” ${ }^{22}$ oraz że nie można wyjeżdżać, nie będąc nieprzygotowanym, czyli bez listy kontaktów. Redakcje domagały się „czegoś, co już nadali inni wcześniej i z większym biglem" ${ }^{23}$. Korespondenci wojenni tworzyli zamknięty, elitarny klub, w którym spotykali się na przykład dziennikarz Reutersa z Kabulu czy korespondent CNN w Islamabadzie. Jednak jak czytamy: „Korespondenci wojenni rzadko działali w zespole, nie lubili dzielić się zdobyczą. Z natury byli samotnymi myśliwymi" ${ }^{24}$. Ich ambicje (na przykład Adama Matyasa w Kaszmirze) wykraczały poza przygotowanie newsów - poszukiwano bowiem oryginalnych materiałów, a zdobycie ich wiązało się zawsze z dużym ryzykiem. Takie mogło grozić po skontaktowaniu się z komendantem powstania mudżahedinów Abdulem Rahmanem. Materiał z tego spotkania dziennikarze wieźli w laptopie i aparatach fotograficznych. Adam, kiedy pojawiał się temat, „zwykle był na miejscu odrobinę przed czasem, wyprzedzając innych, obdarzonych jedynie ślepym instynktem" 25 . Odbiorcy byli zainteresowani tematyką wojenną, a tymczasem efekty pracy dziennikarzy nie zawsze były zadowalające, na przykład z Kaszmiru przywieźli jedynie trochę zdjęć z powstania i kilka wywiadów z pomniejszymi komendantami.

Poznajemy też byłego dziennikarza Boba Nelsona (obecnie najemnika, przemytnika), który pojechał wcześniej do Kabulu nadać wiadomość o udziale Pakistanu w rewolucji talibów. Talibowie nie dopuszczali do siebie dziennikarzy cudzoziemców. Ci śledzili więc też na bieżąco informacje w miejscowej prasie. Caroline w oczekiwaniu na wydarzenia wojenne przygotowywała w New Delhi fotoreportaż o życiu miejscowych ludzi.

Zaginiony półtora roku wcześniej Francuz Seymour i towarzyszący mu Clifford nadali z Kabulu („Z pola minowego”) relację telewizyjną. Mieli przeprowadzić wywiad z Massudem. Nelson odmówił towarzyszenia mu. W ślad za zaginionymi dziennikarzami wyjechała do Afganistanu sama Caroline, mąż odmówił

\footnotetext{
21 G. Jagielska, Korespondent, Warszawa 2004.

22 Ibidem, s. 157.

23 Ibidem, s. 153.

24 Ibidem, s. 149.

25 Ibidem, s. 151.
} 
towarzyszenia jej - nie chciał dłużej „obsługiwać” wojen. W Kabulu, gdzie powieszono prezydenta i odbywały się publiczne egzekucje, bohaterka zastała „najazd” talibów. Podczas tej rewolucji islamskiej władzę sprawował Najwyższy Mułła. Korespondenci tworzyli tu wspólnotę spotykającą się w Klubie Niemieckim. Odbywały się konferencje prasowe. Miejscowe Radio Kabul zostało przemianowane na Szarijat. Caroline bezskutecznie próbowała dowiadywać się o los zaginionego Francuza, w jego poszukiwaniu towarzyszył jej doktor Ismael Lufti. Ona sama także zaginęła, o czym informowały media. Tym razem Adam zorganizował dziennikarskie ekipy poszukiwawcze.

Uczucia przedstawione $\mathrm{w}$ analizowanych utworach Jagielskiej, dylematy etyczne jej bohaterów wywierają wpływ na czytelnika, tym bardziej że jako świadek zdarzeń Jagielska doświadczyła sytuacji ekstremalnych (zamachy, zbrodnia, wojna, terror), stąd opowieści reporterskie pełne są dramatyzmu. Rodzaj dziennikarstwa „wydarzeniowego”, uprawianego przez męża, porównywała do uzależnienia, „nieustabilizowania”, „improwizacji”. Dom dla reportera był azylem bezpieczeństwa.

W powieści Jagielskiej Fastryga ${ }^{26}$ wojna bezpośrednio i pośrednio wpłynęła na życie i psychikę bohaterów - trzy pokolenia kobiet z rodziny Werskich: Krystynę, jej córki Ewę i Melę oraz babcię Leonię Werską. Rodzina ukrywała Żydów z getta, stąd nieustanna bojaźń przed Niemcami. Po wojnie utraciła „dom, park i pola”. Lękiem napawały bohaterów nie tylko problemy bytowe (Krystyna bała się utraty pracy), ale i choroby panujące w rodzinie (kaleka Mela), ale przede wszystkim skomplikowane relacje rodzinne - wzajemne zniewolenie, przemoc, sprawcy i ofiary. Na przykład Ewa bała się męża Marka Karasia, który ją bil - miała w sobie „stałą gotowość bólu”. Jak czytamy: „Teraz strach był zaborczy, nie pozostawiał miejsca na nic innego, pochłonął ją w całości”27. Przed atakami furii Marka musiała się z dziećmi ukrywać. Z kolei Marek bał się tego, że kiedy żona malarka będzie się realizowała zawodowo, odejdzie od niego i zabierze dzieci. Pod wpływem nieustannego stresu Ewa popadła w alkoholizm.

W przypadku Krystyny lękom i bojaźni o córki towarzyszyła samotność: „... [ lęki głębiły ją latami. Że nie utrzyma dzieci, kiedyś nie zapłaci za prąd, że zdoła pracować jeszcze dziesięć, piętnaście lat, a potem co, potem co?”28.

Płaskuda ${ }^{29}$ to z kolei powieść przedstawiająca równoległe historie trzech par bohaterów, których łączy nie tylko miejsce zamieszkania - wspólna kamienica - ale i towarzyszące im lęki egzystencjalne oraz niespełnione pragnienia.

${ }^{26}$ G. Jagielska, Fastryga, Warszawa 2006.

27 Ibidem, s. 219.

${ }^{28}$ Ibidem, s. 139.

29 G. Jagielska, Płaskuda, Warszawa 2010. 
Julek, bojąc się samotności, chciał zatrzymać Ankę próbującą swych sił w dziennikarstwie, a jednocześnie oddalającą się od niego. Tak bardzo wciągnął ją materiał do przygotowywanego reportażu o Czeczence, że „tworzyły własne terytorium”. Larysa w wyniku wojny utraciła bliskich, za życia „przechodząc na drugą stronę". Bohaterka reportażu opowiedziała Ance o swoich lękach, strachach, przerażeniu.

Krzysztof z bojaźni nie chciał się przyznać żonie Małej, że stracił pracę. Powodem jego strachu była „Obliczarka” przypominająca o płatnościach, wydatkach, ratach.

Poznajemy też inną parę - Kochanego i Kochanej. Lęki Kochanego, prezentera telewizyjnego, wynikają z niepewności, czy dostanie upragniony talk-show w Trójce lub autorski program w kablówce. Przytoczmy fragment nawiązujący do tytułu powieści: „Płaskudy albo Wielgusy. Kochana rysowała palcem na szybie. Tak się nazywały. Powstawały z czegoś małego, człowiek nigdy nie wiedział z czego, i rosły w oczach, aż było już za późno. Strasznik straszliwy był płaskudą"30.

W najnowszej książce Jagielskiego Wszystkie wojny Lary ${ }^{31}$ bohaterka - pochodząca z Kistów aktorka - żyła w nieustannym lęku o synów: Szamila i Raszida. Ich śmierć pogrążyła ją w wielkim bólu. Synowie udali się do Syrii, by wziąć udział w „świętej wojnie”. Mimo że matka pojechała za nimi, nie udało jej się ustrzec ich przed nieszczęściem. Męczeńską śmierć synów szahidów, mudżahedinów poprzedziła też utrata czeczeńskiego męża i śmierć dwóch braci. Jak czytamy w książce: „Mówiła o wojnie, która jak klątwa wlokła się za nią krok w krok, nie pozwalając o sobie zapomnieć i odbierając po kolei wszystko, co kochała i co miało dla niej wartość”32.

Wcześniej Lara wiodła spokojne i beztroskie życie. Z czasem dopiero pojawiły się pierwsze wątpliwości, niepokój i złe przeczucia:

Uczucie, którego wcześniej nie doznała, jak zmora, pojawiło się na mgnienie oka, czasem na dłuższą chwilę i odchodziło. Zawsze pozostawiało jednak po sobie ślad, uścisk w gardle, szorstki i dławiący. Nie można już było powstrzymać łez, a obezwładniający żal odbierał wolę działania, wszelką ochotę i sprawiał, że każdy wysiłek, każdy zamysł, wydawał się pozbawiony celu, niedorzeczny ${ }^{33}$.

Napięcie zewnętrzne i czekanie na bieg zdarzeń było skutkiem wojen w Gruzji i Czeczenii oraz pogarszających się w związku z tym warunków życia. Z czasem zawładnął bohaterką niepokój wewnętrzny dominujący nad uczuciami i myślami. Małżonkowie oddalali się od siebie, gdyż mąż nie dostrzegał niebezpieczeństwa.

30 Ibidem, s. 228.

31 W. Jagielski, Wszystkie wojny Lary, Kraków 2015.

32 Ibidem, s. 25.

33 Ibidem, s. 46. 
Zresztą lęk bohaterki o los małżeństwa ustępował przed bojaźnią o dzieci, które chciała wywieźć z miasta, ustrzec przed nieszczęściem. Dwukrotna ucieczka Lary z synami przed widmem wojny była próbą ocalenia dzieci przed złem. Wojna nie pozwalała jednak o sobie zapomnieć. Także rodzinna dolina po drugiej stronie Kaukazu nie była dla bohaterki zacisznym schronieniem, miejscem bezpiecznym, choć wydawało jej się, że „nie wpuści pod własny dach wojny”.

Wojna zmieniła ludzi. Bohaterce udzielał się strach, dom przestał istnieć. Kiedy mąż wywiózł synów do Europy, niepokój trwał - wciąż oczekiwała na wiadomości o synach i od synów. Niepokojowi towarzyszyła tęsknota. Łączność internetowa $\mathrm{z}$ synami i ich rodzinami nieco osłabiła te uczucia. Wyobcowanie synów w kulturze europejskiej doprowadziło do coraz silniejszych więzi ze środowiskiem muzułmańskich salafitów. To znów było powodem, iż Lara „poczuła pierwsze drobne iskierki strachu" ${ }^{34}$. Podczas odwiedzin synowie wydali jej się obcy, zagadkowi, choć w swych wyborach szczęśliwi. Mimo tego był to „czas niespiesznego nasycania się radością, która zastąpiła niepewność i lęk"35. Wiele spraw ukrywano przed matką, ale i tak - jak mówiła: „Tylko na sercu poczułam taki straszny ciężar i w gardle tak mnie ścisnęło, że ledwo mogłam słowo wykrztusić”36. Kolejne lęki, strach, niepokój bohaterki wiązały się z jej wyprawą do syna na froncie syryjskim - bała się tego, co ją czeka, obawiała się, czy sobie poradzi w drodze przez granice. Wciąż jednak sądziła, że uratuje synów od śmierci. To, co zobaczyła w Syrii („Istne piekło na ziemi”), doprowadziło ją do rozpaczy. Gdy po śmierci Szamila nie miała wiadomości od młodszego syna, czuła grozę, rozpacz. Towarzyszące jej wciąż nerwy i troski odbiły się na jej zdrowiu. A wkrótce musiała także przeżyć wiadomość o utracie Raszida.

Żyjemy w czasach kultury afektu, humanistycznego zwrotu afektywnego ${ }^{37}$. Kategorie uczuć i afektów - w tym lęk - rzutują na tak zwane gatunki afektywne, w których dominuje wymiar emotywny (na przykład reportaże), oddający stany emocjonalne dziennikarzy.

Współwystępujące lęki wojenne i rodzinne/osobiste stanowią wspólny mianownik analizowanych tekstów. Złe myśli bohaterów najpierw były przyczyną bezsenności. Stopniowo narastały, zmieniając psychikę bohaterów, wpływając na ich życie i nich samych. Utwory Jagielskich przynoszą duży ładunek emocji

\footnotetext{
34 Ibidem, s. 128.

35 Ibidem, s. 137.

36 Ibidem, s. 165.

37 Por. Kultura afektu - afekty w kulturze. Humanistyka po zwrocie afektywnym, red. R. Nycz, A. Łebkowska, A. Dauksza, Warszawa 2015.
} 
- znajdujemy w nich liczne opisy zniszczeń wojennych (na przykład Groznego), drastyczne i naturalistyczne opisy rannych, uchodźców, śmierci. Te opowieści i szczegółowe opisy poruszają czytelników, powodują w nich silne przeżycia; emocje autorów udzielają się odbiorcom ich książek. Analizowane teksty dowiodly, iż dziennikarstwo i literatura to obszary wzajemnie się przenikające (tematy, obrazowość, techniki literackie), a dyskursy fikcjonalne współwystępują w dorobku autorów $\mathrm{z}$ dokumentalnymi i autobiograficznymi. 


\section{BIBLIOGRAFIA}

Jagielska G., Anioły jedza trzy razy dziennie, Kraków 2014.

Jagielska G., Fastryga, Warszawa 2006.

Jagielska G., Korespondent, Warszawa 2004.

Jagielska G., Mitość z kamienia. Życie z korespondentem wojennym, Kraków 2013.

Jagielska G., Płaskuda, Warszawa 2010.

Jagielski W., Wszystkie wojny Lary, Kraków 2015.

Arystoteles, Retoryka. Poetyka, przeł. H. Podbielski, Warszawa 1988.

Dziennikarstwo a literatura $w$ XX i XXI wieku, red. K. Wolny-Zmorzyński, W. Furman, J. Snopek, Warszawa 2011.

Jagielski W., Nie wybratem sobie wojen, [w:] Biblia dziennikarstwa, red. A. Skworz, A. Niziołek, Kraków 2010.

Kultura afektu - afekty $w$ kulturze. Humanistyka po zwrocie afektywnym, red. R. Nycz, A. Łebkowska, A. Dauksza, Warszawa 2015.

Mistrzowie literatury czy dziennikarstwa?, red. K. Wolny-Zmorzyński, W. Furman, J. Snopek, Warszawa 2011. 